\title{
LOS DERECHOS DE DEFENSA Y EL DEBER DE COLABORACIÓN CON LA ADMINISTRACIÓN TRIBUTARIA*
}

\author{
Defense rights and the duty of collaboration \\ with the tax administration
}

\author{
Montserrat Hermosín Álvarez \\ Universidad Pablo de Olavide (España) \\ mheralv@upo.es
}

http://dx.doi.org/10.18543/ed-66(2)-2018pp219-248

Recibido: 30.10 .2018

Aceptado: 21.11.2018

\section{Resumen}

Frecuentemente, se ha advertido acerca de la eventual colisión que podría suscitarse entre el derecho fundamental a no autoinculparse (art. 24.2 CE) y el deber de colaboración con la Administración que impone al contribuyente la exigencia de comunicar y aportar datos relativos a sus obligaciones tributarias (arts. 31 CE y 93.1 Ley General Tributaria).

El posible conflicto se pone de manifiesto si esos datos -obtenidos bajo amenaza de sanción- pudieran ser usados en un procedimiento sancionador o en un ulterior proceso penal. En el presente trabajo trataremos de indagar en sus contenidos y exigencias teniendo en cuenta la Jurisprudencia Constitucional y del Tribunal Europeo de Derechos Humanos, para poder llegar a una posición integradora de ambos

* Cómo citar / Citation 'Chicago-Deusto' (Autor-fecha / Author-date / Lista de referencias / Reference list entries): Hermosín Álvarez, Montserrat. 2018. «Los derechos de defensa y el deber de colaboración con la Administración Tributaria». Estudios de Deusto 66, n. ${ }^{\circ}$ 2: 219-248. http://dx.doi.org/10.18543/ed-66(2)-2018pp219-248. 
intereses constitucionalmente protegidos como elemento indispensable para el funcionamiento de un Estado de Derecho.

\title{
Palabras clave
}

Deber de colaboración; derecho a no autoincriminarse; procedimiento sancionador; Administración tributaria.

\begin{abstract}
The possible collision between the right to non-self-incrimination (art. 24 CE) and the obligation to collaborate with the Tax Administration has frequently been revealed. This duty imposes on the taxpayer the requirement to provide data related to his tax obligations (arts. 31 CE y 93.1 Ley General Tributaria).

The conflict arises whether those data obtained under threat of sanction could be used in a subsequent sanctioning procedure. In this work we will analyze the contents of these constitutional values taking into consideration the Constitutional jurisprudence and the jurisprudence of the European Court of Human Rights.
\end{abstract}

\section{Keywords}

Obligation to cooperate; right against self-incrimination; sanction procedure; Tax Administration. 


\begin{abstract}
SUMARIO: I. INTRODUCCIÓN Y PLANTEAMIENTO. II. LOS DERECHOS DE DEFENSA DEL OBLIGADO TRIBUTARIO Y EL DEBER DE CONTRIBUIR. III. LA JURISPRUDENCIA DEL TRIBUNAL EUROPEO DE DERECHOS HUMANOS. IV. LA JuRisprudencia del Tribunal Constitucional. V. Cesión de datos OBTENIDOS EN LOS PROCEDIMIENTOS DE APLICACIÓN DE LOS TRIBUTOS. VI. CESIÓN O UTILIZACIÓN DE DATOS EN LOS PROCEDIMIENTOS SANCIONADORES. 1. Separación del procedimiento sancionador tributario de «segundo grado». 1.1. Incorporación de los datos obtenidos en los procedimientos de aplicación de los tributos al procedimiento sancionador. 1.2. Datos que constituyen una declaración autoincriminatoria. 1.3. Derecho al juez imparcial. 2. Separación del procedimiento sancionador de «primer grado». 2.1. Separación orgánica. 2.2. Régimen probatorio diferenciado. VII. REFLEXIÓN FINAL.
\end{abstract}

\title{
I. INTRODUCCIÓN Y PLANTEAMIENTO
}

La Administración tiene reconocida por el artículo 25 de la Constitución el ejercicio de la potestad sancionadora. De toda la gama de sanciones existentes la única que se le ha sustraído ha sido la pena privativa de libertad cuya imposición pertenece en exclusiva al orden penal. Ante este vasto ius puniendi de la Administración, muchos contribuyentes nos planteamos qué tipo de derechos y garantías se le reconocen al presunto infractor tributario.

Si miramos atrás, en la antigua Ley General Tributaria de 1963 la sanción era un elemento más de la cuota y el procedimiento para su imposición no era otro, que el procedimiento para la aplicación de los tributos. No existía como tal un procedimiento sancionador separado de los procedimientos de gestión e inspección. y mucho menos, dentro del propio procedimiento sancionador tampoco se le atribuían sus fases de instrucción y resolución a órganos diferentes $^{1}$. No en vano, la doctrina comenzó a reclamar la separación de estos procedimientos para evitar la imposición de sanciones automáticas. Con esta unidad de procedimientos «unos mismos hechos inevitablemente conectados $\mathrm{y}$, por tanto, ambivalentes en cuanto a su alcance probatorio (la realización

${ }^{1}$ Por ello Casado Ollero, G., destacó durante los años noventa como la inspección tributaria se había convertido en una auténtica policía fiscal durante la tramitación del procedimiento de gestión tributaria, «procedimiento en el que se ejercitan no tanto potestades y funciones liquidatorias sino de policía fiscal, y dirigido a la investigación y fijación no sólo de hechos imponibles sino de hechos -y conductas- determinantes de la sanción fiscal» (en AA VV, Estudios de Derecho Tributario en Memoria de maría del Carmen Bollo Aracena, (Universidad del país Vasco, Bilbao, 1993), págs. 160 a 161). 
del hecho imponible y la conducta infractora que consiste, precisamente en su ocultación total o parcial), constituyen la base de un único procedimiento) $\rangle^{2}$.

Sin embargo, apareció en nuestro ordenamiento jurídico una norma que parecía marcar un antes y un después en los procedimientos tributarios. La Ley 1/1998, de Derechos y Garantías de los Contribuyentes trató de encontrar un punto de equilibrio en esta situación y estableció por primera vez la separación entre los procedimientos de liquidación y el procedimiento sancionador ya que, su fundamento es radicalmente distinto. El artículo 34 parecía incorporar una gran novedad a los procedimientos tributarios conocida como «garantía de procedimiento» ${ }^{3}$. No obstante, más que una garantía, la separación de procedimientos generó trámites formales pero sin llegar a lograr una distinción real y efectiva, ni una mejor salvaguarda de los derechos de defensa del obligado tributario ${ }^{4}$.

Inspirada en esta última norma la nueva Ley General Tributaria acogió el procedimiento sancionador separado como principio general del resto de procedimientos de aplicación de los tributos (art. 208 LGT) aunque ha revelado una deficitaria regulación en la materia que nos ocupa ${ }^{5}$. Las diversas actuaciones y prerrogativas llevadas a cabo por la Administración durante el desarrollo de los procedimientos de aplicación de los tributos y en el seno de

2 Soler Roch, M $\mathrm{M}^{\mathrm{a}} \mathrm{T}$., «Deberes tributarios y derechos humanos», Revista Técnica Tributaria, núm. 30, (1995): pág. 113.

${ }^{3}$ El artículo 34 de la Ley de Derechos y Garantías de los Contribuyentes «exige la existencia de un procedimiento separado para la imposición de sanciones que se llevará a cabo mediante un expediente distinto e independiente del instruido para la comprobación e investigación de la situación tributaria lo que no quiere decir órganos distintos» (Casanova Caballero, C., en AA VV, coord. Mantero Sáenz, A. y Jiménez-Reyna Rodríguez, E., Ley General Tributaria, Antecedentes y Comentarios, (Asociación Española de Asesores Fiscales, Madrid, 2005), pág. 881).

4 Según Banacloche Pérez-Roldán, J., «la realidad práctica ha reducido esta previsión legal a un mayor «papeleo», por supuesto preimpreso». Afirma también el autor que «el procedimiento separado no ha supuesto más que desgajar de las actas las referencias a las Sanciones. A partir de ahí se produce el empleo de una nueva documentación, casi normalizada» (Los Derechos del Contribuyente, (La Ley, Madrid, 2000), págs. 221y ss).

${ }^{5}$ Como advirtió Juan Lozano, A. Ma ${ }^{\text {. }}$, «las mayores dificultades para articular una solución que permita hacer realidad la independencia funcional de ambos tipos de actuaciones siguen radicando en el mecanismo que se arbitre para garantizar simultáneamente la pervivencia de los deberes de colaboración con la administración en el curso de las actuaciones de comprobación e investigación, y la efectiva salvaguarda de la presunción de inocencia con sus garantías de no autoinculpación en el procedimiento sancionador» («Una propuesta para la articulación entre los procedimientos tributarios sancionadores y los desarrollados por los órganos de gestión e inspección en orden a la aplicación de los principios constitucionales», CEF, Revista de Contabilidad y Tributación, núm. 173, (1997): pág. 44). 
los procedimientos sancionadores se siguen encontrando interrelacionadas, siendo muy difícil determinar en qué momento se cierra un procedimiento y cuando comienza el otro.

Sin lugar a dudas, los derechos de defensa del obligado tributario se encuentran en un contexto normativo indeterminado, acrecentado por las divergencias que derivan de la jurisprudencia constitucional y del TEDH y las discordantes opiniones de la doctrina científica.

En el presente estudio intentaremos llevar a cabo un acercamiento a una de las cuestiones más controvertidas del derecho tributario, el posible equilibrio entre los derechos defensa y el deber de colaboración con la Administración tributaria, tomando en consideración el tratamiento que le han dispensado tanto el Tribunal Constitucional como el Tribunal Europeo de Derechos Humanos (TEDH).

\section{LOS DERECHOS DE DEFENSA DEL OBLIGADO TRIBUTARIO Y EL DEBER DE CONTRIBUIR}

A lo largo de los últimos años estamos asistiendo a un incremento notable de las obligaciones de colaboración y de suministro de información a la Administración tanto a nivel estatal, europeo e internacional ${ }^{6}$. En el curso de estas actuaciones que persiguen una mejor eficacia de nuestros sistemas impositivos, se tienen que tomar también en consideración las garantías de defensa del contribuyente que, como derechos fundamentales no son renunciables ni prescindibles en ningún momento procedimental ${ }^{7}$.

${ }^{6}$ Vid. Rozas Valdés, J.A., «Los sistemas de relaciones cooperativas: una perspectiva de derecho comparado desde el sistema tributario español», Documentos IEF, núm. 6, (2016): pág. 7. Quien ha advertido que una manera para «luchar contra la erosión de la capacidad tributaria de los Estados consiste en poner en común los recursos caminando hacia una estandarización internacional de sus sistemas tributarios y de los procedimientos por los que discurre su aplicación efectiva». Respecto a la Directiva (UE) 2016/343, de 9 de marzo de 2016 se ha señalado que refuerza las garantías procesales dentro del espacio europeo de justicia, pero «lamentamos su enfoque poco ambicioso y, en definitiva, que haya optado por una armonización de las disposiciones nacionales a la baja (...)». Sería conveniente que «la Unión Europea reforzase sin demora el derecho a no autoinculparse y la presunción de inocencia, en general y también en materia tributaria» (Sanz Díaz-Palacios, J.A., «La Directiva (UE) 2016/343 y el Derecho a no autoinculparse en materia tributaria», Crónica Tributaria, núm. 162, (2017): pág. 133).

7 Sin embargo, «la coexistencia de procedimientos -administrativo y penal-, la comunicación de las pruebas obtenidas en el procedimiento de inspección en el que se practica la liquidación, y el incremento de la sanción por excusa, negativa o resistencia a la actuación inspectora, ponen de manifiesto el riesgo que el nuevo sistema supone en relación con el derecho a no declarar contra sí mismo y a no confesarse culpable, y en consecuencia sobre el derecho a la tutela judicial efectiva del contribuyente considerado 
En el artículo 31.1 de la Constitución se reconoce el deber de contribuir como sustento primordial para el funcionamiento del sistema tributario, a tenor del cual «Todos contribuirán al sostenimiento de los gastos públicos de acuerdo con su capacidad económica mediante un sistema tributario justo inspirado en los principios de igualdad y progresividad que, en ningún caso, tendrá alcance confiscatorio». Una de las manifestaciones del deber de contribuir $^{8}$ es el artículo 93 de la Ley General Tributaria ${ }^{9}$ donde se establece que «Las personas físicas o jurídicas, públicas o privadas, así como las entidades mencionadas en el apartado 4 del artículo 35 de esta ley, estarán obligadas a proporcionar a la Administración tributaria toda clase de datos, informes, antecedentes y justificantes con trascendencia tributaria relacionados con el cumplimiento de sus propias obligaciones tributarias o deducidos de sus relaciones económicas, profesionales o financieras con otras personas ${ }^{10}$.

Además, la propia LGT en el art. 29.2, letra f, advierte de la imposición de sanción a todos aquellos obligados tributarios ${ }^{11}$ que no cumplan con «la obligación de aportar a la Administración tributaria libros, registros, documentos o información que el obligado tributario deba conservar en relación con el cumplimiento de las obligaciones tributarias propias o de terceros así como cualquier dato, informe, antecedente y justificante con trascendencia

en este momento como un presunto delincuente fiscal» (Martínez Muñoz, Y., «Los procedimientos tributarios y el delito fiscal en la Ley General Tributaria. Un análisis en el marco de los principios fundamentales del ordenamiento tributario», Quincena Fiscal, núm. 6, (2016): BIB 2016/1022, pág. 11).

${ }^{8}$ Como muy bien ha advertido Casado Ollero, G., «La obligación de proporcionar a la Administración Tributaria datos, informes o antecedentes con trascendencia tributaria, constituye una manifestación de los llamados doctrinalmente «deberes de colaboración» - Mitwiekungspflichten -, en la doctrina alemana encuadrables en la categoría más amplia de los deberes de prestación a que implícitamente se refiere el art. 31.3 de la Constitución Española» («La colaboración con la Administración tributaria. Notas para un nuevo modelo de relaciones con el fisco», HPE, núm. 68, (1981): pág. 156

9 Desarrollado por los arts. 30 y ss del Real Decreto 1065/2007, de 27 de julio, por el que se aprueba el Reglamento General de las Actuaciones y los Procedimientos de gestión e inspección tributaria y de desarrollo de las normas comunes de los procedimientos de aplicación de los tributos.

${ }_{10}$ Tal y como se ha apuntado «al gasto se contribuye no solamente realizando prestaciones dinerarias, sino, además, mediante la ordenación de las conductas ciudadanas conforme a las exigencias del ordenamiento tributario y que no deben ser otras que aquellas que permitan la más eficaz aplicación de los tributos» (Eseverri Martínez, E., «Las posiciones subjetivas derivadas de la aplicación del tributo», Estudios de Derecho y Hacienda, (Homenaje a César Albiñana García-Quintana, T. II, Madrid, 1987), pág. 862).

11 Tampoco se puede «excluir de entrada el deber de colaboración del contribuyente en tanto que del mismo podría derivarse una actuación sancionadora» (STSJ de Cataluña, de28 de septiembre de 2012, FJ 5º (PROV 2012, 384484)). 
tributaria, a requerimiento de la Administración o en declaraciones periódicas. Cuando la información exigida se conserve en soporte informático deberá suministrase en dicho soporte cuando así fuese requerido».

Pero no podemos perder de vista que la Administración tributaria puede castigar las conductas ilícitas de los administrados, ejerciendo una de las manifestaciones del ius puniendi estatal, reconocido por el artículo 25 de la Constitución española y que por lo tanto, la culpabilidad no podrá ser probada por la sola incorporación de los datos obtenidos en los procedimientos de aplicación de los tributos bajo amenaza de sanción y en cumplimiento del deber constitucional de contribuir ${ }^{12}$. Por ello, establece el art. 178 de la LGT que la potestad sancionadora en materia tributaria se ha de ejercer conforme a los principios reguladores en materia administrativa, con las especialidades previstas en esta Ley, destacando en particular determinados principios aplicables en este ámbito, tales como el de legalidad, tipicidad, responsabilidad, proporcionalidad y no concurrencia. En definitiva, se han de salvaguardar también los derechos fundamentales de defensa del administrado.

En el artículo 24.2 de la Constitución se recoge el derecho a no autoinculparse estableciendo que, «(...) todos tienen derecho al Juez ordinario predeterminado por la ley, a la defensa y a la asistencia de letrado, a ser informados de la acusación formulada contra ellos, a un proceso público sin dilaciones indebidas y con todas las garantías, a utilizar los medios de prueba pertinentes para su defensa, a no declarar contra sí mismos, a no confesarse culpables y a la presunción de inocencia».

A nivel internacional, también el Convenio Europeo para la Protección de los Derechos Humanos y de las Libertades Fundamentales de 4 de noviembre de 1950 (RCL 1977, 893) incluye este derecho, dentro del derecho a un proceso equitativo, reconociendo en el artículo 6 que «Toda persona tiene derecho a que su causa sea oída equitativa, públicamente y dentro de un plazo razonable, por un tribunal independiente e imparcial, establecido por la Ley, que decidirá los litigios sobre sus derechos y obligaciones de carácter civil o sobre el fundamento de cualquier acusación en materia penal dirigida contra ella». El apartado 2 continúa proclamando la presunción de inocencia cuando establece que «Toda persona acusada de una infracción se presume inocente hasta que su culpabilidad haya sido legalmente declarada». Finalmente, el

${ }^{12}$ Como ha manifestado el Tribunal Supremo en varias ocasiones podría considerarse coacción suficiente «cualquier medio que suponga una coacción o compulsión, incluso jurídica, en el sentido de contraposición de consecuencias jurídicas gravosas contra los intereses jurídicos de la persona acusada por el solo hecho de no colaborar con la actuación investigadora de las autoridades» (Sentencias 487/2015, de 20 de julio (RJ 2015, 3940); 129/2014, de 26 de febrero (RJ 2014, 1574) y 245/2012, de 27 de marzo (RJ 2012, 4649) ). 
apartado 3 engloba una serie de derechos y garantías procesales para la salvaguarda del derecho de defensa ${ }^{13}$.

Aunque el art. 6 del Convenio europeo de Derechos Humanos no enu-

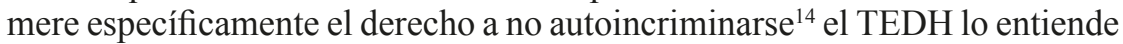
incluido en este precepto en una consolidada jurisprudencia ${ }^{15}$.

Parece que nos hallamos ante bienes jurídicos constitucionalmente protegidos, pero aparentemente contrapuestos. Las garantías de tutela de la protección del contribuyente «en conjunción con el principio de proporcionalidad deben conducir a tener conocimiento de hasta qué punto o en qué medida debe «ceder» o no un derecho fundamental frente a la realización del deber de contribuir, materializado en las actuaciones de obtención de información» ${ }^{16}$. Por ello, resulta imprescindible encontrar un mínimo equilibrio para que el presunto infractor pueda ejercitar sus derechos de defensa, sin la incorporación de elementos de prueba autoincriminatorios aportados coactivamente, o de lo contrario, este modus operandi determinará que la sanción que se vaya a imponer sea de cuestionable validez en nuestro ordenamiento constitucional.

\section{LA JURISPRUDENCIA DEL TRIBUNAL EUROPEO DE DERECHOS HUMANOS}

Resulta trascendental tomar como punto de partida en nuestro análisis la jurisprudencia del TEDH ya que el mismo ha realizado grandes aportaciones al concepto de declaración autoincriminatoria ${ }^{17}$.

El TEDH ha reconocido como violaciones en procedimientos instruidos por la Administración en los que se ha ejercido una coacción sobre los particulares con la finalidad de que aportasen pruebas en procedimientos

13 Sobre el alcance de este precepto Marino, Giuseppe, «Limitation of administrative penalties by the European Convention of Human Rights and the EU Charter of fundamental rights», Thematic Report, EATLP (2015), Milan, Congress on «Surcharges and penalties in Tax Law».

14 Vid. Frommel, Stefan N., «El Tribunal Europeo de Derechos Humanos y el derecho del acusado a no declarar: ¿puede ser invocado por los contribuyentes?», Revista de Derecho Financiero y Hacienda Pública, núm. 236, (1995): pág. 455.

15 Entre otras: Sentencias de 3 mayo de 2001, J.B. contra Suiza, (TEDH 2001, 322); de 17 de diciembre de 1996, Saunders contra el reino Unido (TEDH 1996, 67); de 14 de febrero de 1994, Bendenoun contra Francia (TEDH 1994, 12) y de 25 de febrero de 1993, Funke contra Francia (TEDH 1993, 7); que serán objeto de análisis más adelante.

${ }^{16}$ Sánchez López, E. M., «Algunas cuestiones controvertidas en relación con los requerimientos de información de terceros. Un análisis jurisprudencial», Quincena Fiscal, núm. 9, (2018): BIB 2018/8646, pág. 24.

17 Vid. Baker, Philip, «Some recent decisions of the European Court of Human Rights on Tax Matters», European Taxation, núm. 55, (2015). 
administrativos que, posteriormente, servirían de fundamento incriminatorio en procedimientos penales ${ }^{18}$. Manifestando que el derecho a no autoinculparse «presupone que las autoridades logren probar su caso sin incurrir a pruebas obtenidas mediante métodos coercitivos de presión en contra de la voluntad de la persona acusada» ${ }^{19}$.

Uno de los pronunciamientos más relevantes en esta materia lo constituyó la Sentencia del TEDH de 25 de febrero de 1993, Funke v. Francia ${ }^{20}$. En este supuesto el Tribunal anuló la imposición de una sanción por la negativa del recurrente a facilitar información, datos y documentos. Entendió el Tribunal que la única finalidad de este requerimiento era la obtención de pruebas para una posterior acusación penal. De este pronunciamiento se puede extraer que el derecho a no declarar contra sí mismo se encuentra contenido en el concepto más amplio «proceso equitativo» del artículo 6 del Convenio. La Corte de Estrasburgo se pronuncia manifestando que la sanción que los tribunales franceses impusieron al recurrente, debido a que no facilitó a la Administración de aduanas los documentos que se le habían requerido, constituye «materia penal» y es contraria al artículo 6.1 pues vulnera el derecho a no declarar contra sí mismo ${ }^{21}$. Hemos de tener en cuenta que la Sentencia Funke

${ }_{18} \mathrm{Al}$ respecto pueden verse los comentarios de Gimeno Valledor, L., «Procedimiento Sancionador Tributario en la nueva Ley General Tributaria. Novedades más relevantes», Boletín del ilustre Colegio de Abogados de Madrid, núm. 8, (2004): pág. 208.

19 Vid. STEDH de 8 de abril de 2004, caso Weh c. Austria (TEDH 2004, 28).

20 Jean-Gustave Funke (fallecido el 22 de julio de 1997), nacional alemán, residía en Francia y ejercía la profesión de representante de comercio. Tres agentes de aduanas y un oficial de la policía judicial se presentaron en su domicilio con el fin de obtener información relativa a sus bienes en el extranjero. El Sr. Funke admitió la titularidad de varias cuentas bancarias en otros países, pero que no tenía en su domicilio ningún justificante de las mismas. Sin embargo, registraron su vivienda y encontraron documentación al respecto exigiéndole al Sr. Funke que entregara documentos bancarios de sus cuentas en Alemania, Polonia y Suiza. Funke se comprometió a aportarlos, pero finalmente comunicó la imposibilidad de aportar la documentación requerida. Finalmente, se impusieron al Sr. Funke dos multas. El Sr. Funke recurrió alegando la violación de los artículos 6 y 8 del Convenio Europeo para la protección de los Derechos Humanos. El Tribunal Europeo declaró que se había violado el derecho a un proceso equitativo del artículo 6 y el artículo 8.

${ }^{21} \mathrm{El}$ «Tribunal constata que las autoridades aduaneras provocaron la condena del $\mathrm{Sr}$. Funke con el fin de conseguir ciertos documentos cuya existencia presumían, aunque no tenían la certeza de ello. Siendo incapaces o no queriendo obtenerlos por otros medios, intentaron obligar al demandante a que proveyera las pruebas de las infracciones que supuestamente había cometido. Pero las características especiales de las leyes sobre derechos de aduanas (...) no pueden justificar una infracción del derecho de toda persona acusada en materia penal, según el significado propio de esta expresión en el artículo 6, a no declarar y a no contribuir a su propia incriminación. En consecuencia, ha existido una violación del artículo 6.1» (Frommel, S.N., «El Tribunal Europeo de Derechos Humanos y el derecho del acusado a no declarar: ¿puede ser invocado por los contribuyentes?», 
se refería a la condena provocada por las autoridades aduaneras francesas con la finalidad de obtener determinados documentos, por consiguiente, podríamos interpretar que la doctrina de este pronunciamiento sobre el derecho a no autoinculparse es aplicable, asimismo, a los litigios judiciales sobre infracciones tributarias ${ }^{22}$.

Un año más tarde la Sentencia del TEDH de 24 de febrero de 1994, Bendenoum v. Francia, sí relaciona el concepto «acusación en materia penal» del artículo 6.1 a los procedimientos jurisdiccionales relativos a ilícitos tributarios, y abre la posibilidad de invocar en esos procedimientos el derecho a no declarar contra sí mismo ${ }^{23}$. Este supuesto resulta trascendental en nuestro ámbito ya que, en el mismo, el TEDH manifestó que el art. 6 del Convenio es plenamente aplicable a los procedimientos tributarios.

Posteriormente, en la Sentencia de 17 de diciembre de 1996, Saunders contra Reino Unido, se anuló la condena impuesta al recurrente ya que la misma se había basado en declaraciones obtenidas en un procedimiento administrativo obtenidas bajo coacción y el derecho a la no autoincriminación resulta exigible en los procedimientos administrativos sancionadores y penales $^{24}$.

trad. Fernández Amor, J.A., Revista de Derecho y de Hacienda Pública, núm. 236, (1995): pág. 488).

${ }^{22}$ Como retóricamente se ha preguntado Frommel, S.N., «¿acaso son las características de las leyes aduaneras distintas a las de las leyes tributarias?» («El Tribunal Europeo de Derechos Humanos y el derecho del acusado a no declarar: ¿puede ser invocado por los contribuyentes?», op. cit., pág. 510).

${ }^{23}$ El Sr. Bendenoum, ciudadano francés, residía en Suiza. Creó conforme al derecho francés una Sociedad Anónima con sede en Estrasburgo, y la dedicó al comercio de monedas antiguas, objetos de arte y piedras preciosas. Las aduanas francesas llevaron a cabo una investigación que también tuvo trascendencia tributaria y penal. El señor Bendenoum presentó alegaciones frente a los informes requeridos por determinados impuestos. Las alegaciones fueron rechazadas y presentó recurso ante el Tribunal administrativo de Estrasburgo. Bendenoum consideraba que se le había privado de su derecho a un juicio justo, pues no se le había permitido examinar la totalidad del expediente instruido por la Administración de Aduanas y acudió a la Comisión Europea de Derechos Humanos. Este órgano estimó que se había violado el derecho a un proceso equitativo, consagrado en el artículo 6 del Convenio. Sin embargo, no es éste el criterio del Tribunal, en la sentencia que comentamos declara que el artículo 6.1 del Convenio es aplicable al supuesto enjuiciado, pero rechaza la demanda. La Corte señala que el propio Sr. Bendenoum y su consejo habían tenido acceso al expediente completo, al menos durante la instrucción penal de la causa.

${ }^{24}$ El TEDH entendió que «el derecho a no declarar contra sí mismo se fundamenta, en primer lugar, en el respeto a la voluntad del acusado a permanecer en silencio. Tal y como entiende habitualmente en el sistema de las partes contratantes y en estos lugares, no se extiende a la utilización en un procedimiento penal del material que pueda obtenerse del acusado mediante poderes coactivos, pero que tiene una existencia independiente 
El Tribunal de Estrasburgo dio un paso más en la STEDH de 3 mayo de 2001, JB v. Suiza. La importancia de este pronunciamiento radica en que el Tribunal dictaminó que el derecho a no autoinculparse no es exigible sólo en relación al procedimiento sancionador, sino que también desplegaría sus efectos en cualquier procedimiento del que pueda derivarse una sanción ${ }^{25}$. Por ello, parte de la doctrina se ha llegado a plantear la validez de nuestro actual procedimiento sancionador vigente en base a la doctrina sentada en este pronunciamiento ${ }^{26}$.

Posteriormente siguió el TEDH ratificándose en la misma línea jurisprudencial y en la STEDH de 5 de abril de 2012, Chambaz c. Suiza, manifestó que el derecho a la no autoincriminación resulta exigible a aquellos procedimientos que se dirijan conjuntamente a liquidar el tributo y a imponer sanciones. Entendió el tribunal que el deber de información en el desarrollo de un procedimiento administrativo vulneraba el derecho a no declararse culpable, aunque el procedimiento penal se inició tiempo después.

De forma continuada el TEDH ha declarado que son inadmisibles las pruebas obtenidas de forma coactiva. En esta línea resulta también la Sentencia del TEDH de 11 de julio de 2006, Jalloh contra Alemania. No obstante, resultan trascendentales las manifestaciones del Tribunal de Estrasburgo en

de la voluntad del acusado, tal y como sucede, inter alia con los documentos obtenidos de acuerdo con un mandato judicial, o muestras de aliento, sangre u orina, o tejido corporal para realizar pruebas de ADN».

${ }^{25}$ En este asunto el Tribunal consideró legítima, la negativa de colaborar del contribuyente y a facilitar información en un procedimiento que se dirigía, al mismo tiempo, a la determinación de las obligaciones fiscales del obligado tributario y al castigo de su incumplimiento (párrafos 47 y 48): «el Tribunal constata que el procedimiento tenía por objeto determinar los impuestos debidos por el recurrente y, llegado el caso, imponer un impuesto suplementario y una multa por defraudación fiscal. No obstante, el procedimiento no se calificaba expresamente como procedimiento para la imposición de impuestos suplementarios o de defraudación fiscal» (47). Pese a ello, «el Tribunal considera, y esto no es objeto de discusión entre las partes, que desde el principio y durante todos los procedimientos, las autoridades tributarias podían haberle impuesto una multa al recurrente a causa de la infracción de defraudación fiscal» (48).

${ }^{26}$ Es el caso de Sánchez Ayuso, I., quien ha manifestado que «Tengo mis dudas, sin embargo, acerca de lo que opinaría el Tribunal sobre tal separación de procedimientos, una vez que se probara, como se puede probar, no sólo que ambos se someten al conocimiento del mismo órgano, sino que, en el caso de la Inspección de los tributos, sistemáticamente se designa instructor del expediente sancionador al mismo funcionario que actuó en el procedimiento de comprobación del que aquél trae causa. Amén de que, según permite la propia Ley, todas las pruebas y circunstancias obtenidas en dichas actuaciones de comprobación se incorporan al expediente sancionador, sin más trámite que una declaración formal del actuario-instructor» («El derecho a no autoinculparse: trascendencia práctica de la Sentencia JB contra Suiza del Tribunal Europeo de Derechos Humanos», Temas Tributarios de Actualidad, abril, (2002): pág. 37). 
el caso para entender el concepto de declaración autoincriminatoria. El Tribunal recuerda respecto a la utilización de pruebas obtenidas en violación del derecho a guardar silencio y del derecho a no autoinculparse que «no se extiende al uso, en un procedimiento penal, de datos que se pueden obtener del acusado recurriendo a métodos coercitivos sino que existen independientemente de la voluntad del sospechoso, por ejemplo, los documentos obtenidos en virtud de una orden, las extracciones de sangre, el aliento, las muestras de orina, cabellos y tejidos corporales con vistas a un análisis de ADN o incluso de voz».

En definitiva, el derecho a la no autoincriminación no es aplicable a los procedimientos tributarios, pero sí si la ley prevé que esos datos se puedan trasladar o usar en procedimientos sancionadores (SSTEDH de 8 de abril de 2004, Weh c. Austria, y de 4 de mayo de 2005, Shannon c. Reino Unido).

Han sido sentencias que han tenido una gran repercusión, sobre todo en una parte de la doctrina por entender que tienen como consecuencia la prohibición de trasladar las pruebas obtenidas en los procedimientos de aplicación de los tributos a los procedimientos sancionadores o penales tributarios, pudiendo llegar a ocasionar efectos disfuncionales en el ordenamiento tributario ${ }^{27}$.

\section{LA JURISPRUDENCIA DEL TRIBUNAL CONSTITUCIONAL}

El sistema europeo de protección de derechos fundamentales supone «una compleja interrelación entre el Tribunal de Estrasburgo y los tribunales nacionales. El efecto de «cosa interpretada» no implica necesariamente una aplicación mecánica de la doctrina del Tribunal» ${ }^{28}$. La materia objeto de nuestro estudio es buen ejemplo de ello ya que la línea seguida por el Tribunal Constitucional no es del todo coincidente con la del TEDH, tal y como pasamos a analizar.

${ }^{27}$ Vid. Rodríguez Bereijo, A., «Derecho penal Tributario y Derecho Tributario Sancionador en España», Revista Iberoamericana de Derecho Tributario, núm. 4, (1997): pág. 69; Mestre García, E. y Cervantes Sánchez-Rodrigo, C.J., Guía de Infracciones y Sanciones Tributarias, op. cit., págs. 267 y ss. También hay quien considera que la utilización de potestades administrativas en el procedimiento de liquidación, para obtener material instructor utilizables en un futuro procedimiento sancionador, constituye un supuesto de desviación de poder, porque aquellas potestades se ejercitan para fines diversos a los atribuidos por el ordenamiento jurídico (Sánchez Huete, M.A., Derechos y Garantías del imputado en el procedimiento sancionador tributario, op. cit., pág. 80).

${ }^{28}$ López Guerra, L., como muy bien advierte el autor, el Convenio representa un standard común, pero un standard común de mínimos, que puede ser complementado por protecciones adicionales a los derechos fundamentales en cada Estado miembro ( «El Diálogo entre el Tribunal Europeo de Derechos Humanos y los Tribunales Españoles. Coincidencias y Divergencias», Teoría y Realidad Constitucional, núm. 32, (2013): pág. 140). 
El Tribunal Constitucional desde su STC 18/1981 ha venido afirmando que los principios penales son aplicables al derecho administrativo sancionador ${ }^{29}$ : «los principios inspiradores del orden penal son de aplicación, con ciertos matices, al derecho administrativo sancionador, dado que ambos son manifestaciones del ordenamiento punitivo del Estado... hasta el punto de que un mismo bien jurídico puede ser protegido por técnicas administrativas o penales, si bien en el primer caso con el límite que establece el artículo 25 en su número $3^{\circ}$, al señalar que la Administración civil no podrá imponer penas que directa o subsidiariamente impliquen privación de libertad $»^{30}$. Anteriormente al pronunciamiento de 1981 del supremo intérprete de la Constitución, también el Tribunal Supremo había desarrollado una importante jurisprudencia en torno a los principios informadores del sistema sancionador administrativo ${ }^{31}$.

Pero esto no significa que se pueda trasladar mecánicamente y sin matices las garantías del orden penal a los procedimientos sancionadores administrativos $^{32}$.

Sin embargo y, a diferencia de lo sucedido con el TEDH no encontramos en la jurisprudencia española ningún pronunciamiento en el que se

${ }_{29}$ STC 18/1981, FJ 4º : En referencia las «denunciadas vulneraciones en el ámbito administrativo del art. 24.2 CE, es indiscutida la aplicación, a los actos y resoluciones de Derecho administrativo sancionador, de los principios sustantivos derivados de dicho precepto constitucional. (...) se ha ido elaborando progresivamente una doctrina que sume la vigencia en el seno del procedimiento administrativo sancionador de un amplio abanico de garantías del art. 24.2 CE. Sin ánimo de exhaustividad, cabe citar el derecho a la defensa, que proscribe cualquier indefensión; el derecho a la asistencia letrada, trasladable con ciertas condiciones; el derecho a ser informado de la acusación, con la ineludible consecuencia de la inalterabilidad de los hechos imputados; el derecho a la presunción de inocencia, que implica que la carga de la prueba de los hechos constitutivos de la infracción recaiga sobre la Administración, con la prohibición de la utilización de pruebas obtenidas con vulneración de derechos fundamentales; el derecho a no declarar contra sí mismo; y, en fin, el derecho a utilizar los medios de prueba adecuados para la defensa, del que se deriva que vulnera el art. 24.2 CE la denegación inmotivada de medios de prueba (por todas, SSTC 7/1998, de 13 de enero (RTC 1998, 7), FJ 5, y 272/2006, de 25 de septiembre (RTC 2006, 272), FJ 2)».

30 SSTC 243/2007, de 10 de diciembre (RTC 2007, 243); 70/2008, de 23 de junio (RTC 2008, 70); y 82/2009, de 23 de marzo (RTC 2009, 82).

${ }^{31}$ Como ha advertido Nieto García, A., «En la elaboración teórica del dogma de la potestad punitiva única del Estado han participado conjuntamente el Tribunal Supremo y el Tribunal Constitucional, con una notoria prioridad cronológica del primero, a quien luego el segundo ha seguido en este punto fielmente. Pero tampoco conviene olvidar que la rotundidad del Tribunal Supremo se ha reafirmado aún más después de haber comprobado que su postura era aceptada por el Tribunal Constitucional», (Derecho Administrativo Sancionador, (3 ${ }^{\text {a }}$ ed., Tecnos, Madrid, 2002), pág. 80).

32 En este sentido, véase las SSTC 161/1997, de 2 de octubre (RTC 1997, 161), 18/2005, de 1 de febrero (RTC 2005, 18), 59/2014, de 5 de mayo (RTC 2014, 59), y más recientemente la STC 54/2015, de 16 de marzo (RTC 2015, 54). 
haya entendido vulnerado el derecho a no autoinculparse por el uso de la información obtenida y datos obtenidos en un posterior procedimiento sancionador $^{33}$.

En cambio, sí tenemos importantes pronunciamientos donde se perfila el contenido del deber constitucional de contribuir en sus diferentes manifestaciones. Así, ha manifestado el Tribunal Constitucional que los deberes de información contenidos en el artículo 93.1 de la LGT son «un instrumento necesario, no sólo para una contribución justa a los gastos generales, sino también para una gestión tributaria eficaz» ${ }^{34}$. Pero no es un derecho absoluto, sino que resulta imprescindible encontrar un equilibrio con el resto de derechos fundamentales del obligado tributario. En el ordenamiento jurídico en su conjunto «no cabe definir ni dotar de contenido a ninguno de sus institutos de manera aislada, sin consideración al resto de institutos y principios que el propio ordenamiento contempla. Menos aún, cuando esos otros institutos y principios tienen ni más ni menos que rango constitucional y, dentro de éste, una posición prevalente $\rangle^{35}$.

El Tribunal Constitucional sí ha hecho referencia a la contraposición entre el deber de contribuir y el derecho a no autoinculparse ${ }^{36}$.

Uno de sus pronunciamientos más importantes en esta materia lo constituyó la Sentencia 76/1990, de 26 de abril, según el cual ${ }^{37}$ :

«Los documentos contables son elementos acreditativos de la situación económica y financiera del contribuyente; situación que es preciso exhibir para hacer posible el cumplimiento de la obligación tributaria y su posterior inspección, sin que pueda considerarse la aportación o exhibición de esos documentos contables como una colaboración equiparable a la «de-

${ }^{33}$ Otras Sentencias han advertido la estrecha relación que en nuestra Constitución tienen los derechos a no declarar contra sí mismo y a no confesarse culpable con los de defensa y de presunción de inocencia. Aquéllos serían garantías o «derechos instrumentales del genérico derecho de defensa, al que prestan cobertura en su manifestación pasiva, esto es, la que se ejerce precisamente con la inactividad del sujeto sobre el que recae o puede recaer una imputación, quien, en consecuencia, puede optar por defenderse en el proceso en la forma que estime más conveniente para sus intereses, sin que en ningún caso pueda ser forzado o inducido, bajo constricción o compulsión alguna, a declarar contra sí mismo, a confesarse culpable» (SSTC 197/1995, de 21 de diciembre, FJ 6; 161/1997, de 2 de octubre, FJ 5º 299/1999, de 13 de diciembre, FJ 33 ; 127/2000, de 16 de mayo, FJ $4^{\circ}$ y $67 / 2001$, de 17 de marzo, FJ $6^{\circ}$ ).

34 Vid. STC 233/2005, de 26 de septiembre (RTC 2005, 233).

${ }^{35}$ Lozano Serrano, C., «El deber de colaboración tributaria sin autoincriminación», Quincena Fiscal, núm. 8, (2015): págs. 21 y ss.

36 Vid. STC 110/1984 y Autos 642/1986 y 982/1986.

37 Posteriormente el Tribunal mantuvo la misma línea en la STC 161/1997, de 2 de octubre (RTC 1997, 161). 
claración» comprendida en el ámbito de los derechos proclamados en los artículos 17.3 y 24.2 de la Constitución» $\left(\mathrm{FJ} 10^{\circ}\right)^{38}$.

Está claro que el deber de colaboración es necesario para la efectividad del deber de contribuir, pero como puede verse, frente a la doctrina sentada por el TEDH sobre el concepto de declaración autoincriminatoria el Tribunal Constitucional acoge una tesis mucho más estricta. Así, señala el Tribunal Constitucional en el Fundamento Jurídico $3^{\circ}$, que «Para los ciudadanos este deber constitucional (deber de contribuir al sostenimiento de los gastos públicos) implica más allá del genérico sometimiento a la Constitución y al resto del ordenamiento jurídico que el artículo 9.1 de la norma fundamental impone, una situación de sujeción y de colaboración con la Administración tributaria en orden al sostenimiento de los gastos públicos[..]».

Posteriormente, en las STC $18 / 2005$, de 1 de febrero, (FJ $2^{\circ}$ ) y STC 68/2006, de 13 de marzo, (FJ $4^{\circ}$ ) el Tribunal Constitucional se ha vuelto a enfrentar con la alegada vulneración del derecho a no autoincriminarse como consecuencia de la condena de un sujeto, presidente y consejero delegado de una sociedad que fue inspeccionada, como autor de dos delitos contra la hacienda pública. El recurrente de amparo alegó que su condena fue consecuencia de los datos que obraban en el informe de la inspección sobre la documentación aportada coactivamente por distintos representantes de la entidad inspeccionada. El Tribunal descartó la pretensión porque:

«Ni el procedimiento de comprobación e investigación tributaria en el que se obtuvo la información incriminatoria se siguió contra el solicitante de amparo, ni durante el curso del citado procedimiento le fueron reclamados... los documentos que contenían dicha información, ni se ejerció coacción de ninguna clase contra él, ni, por último, el finalmente condenado aportó dato alguno que contribuyera a su propia incriminación» (STC 18/2005, de 1 de febrero, FJ $2^{\circ}$ ).

Como puede verse, el Tribunal Constitucional no entró en la confrontación de estos derechos y el deber de colaboración ya que, había sido una persona jurídica la obligada a aportar y suministrar datos, eludiendo de esta forma cualquier análisis respecto al derecho de autoinculpación al manifestar que «no apreciándose la existencia del requisito subjetivo que la coacción haya sido ejercida por el poder público sobre la persona que facilitó la

${ }^{38}$ Como ha destacado Casas Agudo, D., «Adentrándonos más en concreto en la interpretación dada por el máximo intérprete de la Constitución, este configurando el derecho a no autoincriminarse como un derecho instrumental al servicio del derecho a la defensa y a la tutela judicial, y estrechamente unido a la presunción de inocencia, ha restringido de modo notorio su ámbito de aplicación» («A vueltas con el derecho a no autoinculparse y su dialéctica con los deberes de colaboración tributaria», Quincena Fiscal, núm. 10, (2017): BIB 2017/11159, pág. 9.). 
información incriminatoria y que finalmente fue la destinataria de las medidas punitivas» $\left(\mathrm{FJ}^{\circ}\right.$ y $6^{\circ}$, STC18/2005) ${ }^{39}$.

Más tarde el Tribunal Constitucional volvió a eludir pronunciarse sobre la aplicación del derecho a no autoinculparse en los procedimientos tributarios, cobijándose en el argumento de que el referido derecho fundamental sólo afecta al imputado y en este supuesto el presunto infractor había intervenido en calidad de administrador de la entidad ${ }^{40}$. En la STC 68/2006, de 13 de marzo, utilizó similares argumentos para negar la vigencia del derecho a no autoinculparse en el procedimiento sancionador tributario, manifestando que, «...ni el procedimiento inspector del que derivó en última instancia la denuncia del Ministerio Fiscal por la comisión de delitos contra la hacienda pública contra el Sr. B. M. se siguió en relación a éste, ni la información que se empleó para fundamentar las condenas que le impusieron en el Juzgado de lo Penal núm. 2 de Palma de Mallorca y la Audiencia Provincial de dicha capital fue aportada por el recurrente bajo coacción...obviamente no habiéndose seguido las actuaciones inspectoras de comprobación e investigación en ningún momento respecto del Sr. B. M., sino única y exclusivamente en relación con la entidad de la que era administrador, Bravo Management, SL, resulta evidente la inconsistencia de la denunciada vulneración del art. 24.2 CE que el recurrente afirma haber padecido al no haber informado la inspección de los tributos desde el inicio del procedimiento «al contribuyente inspeccionado» de sus derechos a no declarar contra sí mismo y a no aportar pruebas que le incriminen».

En nuestra opinión, no se puede perder de vista que no son o no deben ser valores contrapuestos, sino que es necesario encontrar un equilibrio entre dos bienes jurídicos constitucionalmente protegidos. Sin embargo, en este caso, el

39 Esta misma línea acerca de la dualidad subjetiva se mantuvo por el Tribunal Constitucional en el auto núm. 186/2008, de 25 de junio, FJ 5º (RTC 2008, 186 AUTO) donde inadmitió a trámite un recurso de amparo presentado por una persona jurídica en un supuesto de datos aportados por terceros.

${ }^{40}$ Con buen criterio se ha manifestado que «la Sentencia no llega a precisar su relevancia, puesto que, amparándose en un formalismo -en una «hábil argumentación» en palabras de Merino Jara- deja sin resolver importantes cuestiones sobre el alcance de este derecho...En nuestra opinión, estas afirmaciones incurren en un formalismo inadmisible. El Tribunal Constitucional tiene razón al afirmar que el derecho a no autoincriminarse sólo puede ser invocado cuando la coacción se haya ejercitado sobre el propio sujeto a quien se impone la medida punitiva. Ahora bien, a nuestro entender, tal circunstancia también puede concurrir en el caso de que la coacción también se haya efectuado sobre una sociedad, cuando la medida punitiva recae sobre un administrador de la misma. Todo dependerá del grado de conocimiento y de control efectivo sobre la información de que haya dispuesto el administrador (en este caso Presidente y Consejero delegado de la Sociedad)» (García-Herrero Blanco, C. y Herrera Molina, P.M., «STC 18/2005, de 1 de febrero: el derecho a no autoincriminarse de los Administradores condenados por delito fiscal», http://www.ief.es/Publicaciones/JurisCons/Comentarios/2005-STC18.pdf). 
supremo intérprete de la Constitución ha eludido entrar en el contenido de esta supuesta confrontación. En otras ocasiones y, con referencia al derecho fundamental de intimidad, sí ha recalcado la necesidad de realizar esta ponderación. En la STC 197/2003, de 16 de junio (RTC 2003, 197), manifestó que: «La colisión entre el derecho fundamental a la intimidad personal y familiar (art. 18.1 $\mathrm{CE}$ ) y el deber constitucional de contribuir a los gastos públicos (art. 31.1 CE) implica la inexistencia, frente a la Administración tributaria u otros poderes públicos, de un pretendido derecho absoluto e incondicionado a la reserva de los datos económicos del contribuyente con trascendencia tributaria (...) pues ello impediría una distribución equitativa del sostenimiento de los gastos públicos en cuanto bien constitucionalmente protegido». Y en la Sentencia 149/2009, de 15 de junio (RTC 2009, 149), señaló que «los valores esenciales que se encuentran en la base del art. 24.2 CE no quedarían salvaguardados si se admitiera que la Administración pudiera compeler u obligar al administrado a confesar la comisión o autoría de los hechos antijurídicos que se le imputan o pudieran imputar o a declarar en tal sentido»».

Manifestaciones todas ellas insuficientes para poder alcanzar el anhelado equilibrio entre el deber de contribuir y el derecho a no autoincriminarse ya que, el máximo intérprete de la constitución ha evitado entrar en el contenido y en la interpretación de estos valores y derechos fundamentales en nuestro ordenamiento jurídico.

Hasta ahora, podemos concluir que frente a la postura del TEDH, el Tribunal Constitucional apoyándose en el deber de contribuir ha dejado claro que la Administración podía imponer a los ciudadanos la obligación de colaborar, exigiéndole la obligación de aportación de pruebas o documentos bajo pena de sanción por su incumplimiento. Pero también señaló nuestro Tribunal que las garantías del artículo 24 de la Constitución y, por lo tanto, el derecho a no declarar contra sí mismo, solo resultaban aplicables a quienes tenían la condición de imputados en un procedimiento penal o sancionador administrativo y en este sentido, consideró que el procedimiento inspector carecía de esta naturaleza.

Desde nuestro punto de vista la normativa tributaria no ha resuelto este problema y la jurisprudencia no ha arrojado luz sobre el mismo. Sigue existiendo una plena intercomunicación entre el procedimiento sancionador tributario y el resto de procedimientos de aplicación de los tributos que, a nuestro juicio, no garantiza en determinados casos el derecho a no autoincriminarse, tal y como pasamos a analizar.

\section{CESIÓN DE DATOS OBTENIDOS EN LOS PROCEDIMIENTOS DE APLICACIÓN DE LOS TRIBUTOS}

En primer lugar, se ha de señalar que el obligado tributario debe colaborar en los procedimientos de aplicación de los tributos por imperativo 
constitucional que tienen como finalidad la correcta determinación y cuantificación de las obligaciones tributarias. El artículo 93 de la LGT establece la obligación de aportar datos e información con «trascendencia tributaria» como manifestación del deber constitucional de contribuir. Como bien manifiesta SÁNCHEZ LóPEZ respecto a los requerimientos individualizados de información que formula la Inspección, al amparo del art. 93 de la LGT habría que tener en cuenta «hasta qué punto las actuaciones de información podrían haber «enmascarado» verdaderas actuaciones de comprobación, vulnerándose, de este modo, los plazos de duración de los procedimientos de comprobación en menoscabo de la seguridad del obligado tributario» ${ }^{41}$.

El problema reside en fijar cuál es el contenido de este concepto indeterminado: «trascendencia tributaria». Es una expresión de muy difícil concreción en la que «los tribunales han ofrecido un concepto de trascendencia tributaria cuyos amplísimos contornos no consiguen sino poner en evidencia la absoluta inseguridad jurídica que existe al respecto» ${ }^{42}$.

No se puede perder de vista que como establece el art. 141.c de la LGT la obtención de información debe ser para la satisfacción del interés público al que se dirige esta potestad, es decir, a «la aplicación de los tributos». Y por lo tanto, no puede presumirse la trascendencia tributaria por el simple hecho de haberse solicitado la información ${ }^{43}$.

Además, el artículo 99.2 de la LGT advierte que «los obligados tributarios pueden rehusar la presentación de los documentos que no resulten exigibles por la normativa tributaria».

Respecto a este concepto jurídico indeterminado, ha precisado el Tribunal Supremo que «la trascendencia tributaria tiene como sustrato la certeza de la existencia de una obligación tributaria, presuntamente incumplida o defectuosamente cumplida por el propio contribuyente, de ahí que el deber de

${ }^{41}$ Sánchez López, E., «Algunas cuestiones controvertidas en relación con los requerimientos de información de terceros. Un análisis jurisprudencial», op. cit., pág. 14.

42 Alonso Gonzalez, L. M., «art. 111 de la LGT», en AA. VV, La Reforma de la Ley General Tributaria. Análisis de la Ley 25/95, de 20 de julio (RCL 1995, 2178), (Cedecs, Barcelona, 1995), pág. 272.

${ }_{43}$ Como ha manifestado la Audiencia Nacional, «conceptuar el requisito legal de la trascendencia tributaria de forma abstracta o genérica equivaldría en la práctica a negar virtualidad a su exigencia, dado que difícilmente puede colegirse, en algún supuesto concreto de información, que sea, en todo caso o circunstancia, directa o indirectamente, tributariamente intrascendente» (SAN de 22 de noviembre de 2012 (JT 2012, 1333)). Anteriormente ya se había señalado que «la «trascendencia tributaria» es un valor anterior a la información requerida, pues si dicha trascendencia tributaria, se aprecia con posterioridad el requerimiento adolece de su esencial requisito» (SAN de 15 de julio de 2010 (JT 2010, 838)). 
información tienda a cumplir el citado interés público; de forma que, el requerimiento de información puede oponerse en el supuesto de que dicho requerimiento no cumpla esas condiciones al haberse desfigurado esa trascendencia tributaria por la indeterminación y la generalidad de la información solicitada» (STS de 28 de noviembre de 2013).

El problema es que se le ha dado una interpretación excesivamente amplia por parte de la jurisprudencia, prueba de ello constituyen las manifestaciones del Tribunal Supremo en las que entiende que para que el requisito de que la información solicitada tenga trascendencia tributaria se entienda cumplido, basta con que dicha utilidad sea potencial, indirecta o hipotética, ya que, los datos solicitados «pueden ser útiles a la Administración para una adecuada gestión de los tributos o en actuaciones de comprobación e investigación, estando los datos solicitados relacionados directa o indirectamente con operaciones de un evidente contenido económico, debe por tanto apreciarse la trascendencia tributaria» (STS de 20 de julio de 2000).

La línea de argumentación seguida por el Tribunal Supremo resulta demasiado imprecisa ya que, posteriormente, afirmó que la obligación de facilitar datos e información "permiten amparar todo requerimiento que venga referido a datos de contenido económico que, de forma directa o interrelacionado con otros, revelen signos de capacidad económica que puedan desencadenar, en el futuro, actuaciones de comprobación por parte de la Administración» (STS de 26 de junio de 2012).

Sin embargo, sobre este aspecto resulta muy la clarificadora la Audiencia Nacional cuando manifiesta que los actos administrativos «se refieren siempre al pasado, y no al futuro, ya que se solicita información o se investiga sobre hechos imposibles ya producidos» (Sentencia de la Audiencia Nacional de 15 de noviembre de 1990). También el TJUE ha reconocido que la trascendencia tributaria debe estar en íntima conexión con la información que solicita la Administración ${ }^{44}$.

A la hora de determinar en qué momento procesal y respecto a que hechos es posible solicitar información, establece el art. 30.3 del RGGIT que «Los requerimientos individualizados de obtención de información respecto de terceros podrán realizarse en el curso de un procedimiento de aplicación de los tributos o ser independientes de este». Respecto a esta cuestión se ha advertido que no significa «que el requerimiento deba ser realizado necesariamente en el seno de un concreto procedimiento de aplicación de los tributos debido a que lo importante es que la Administración pueda fundamentar la relevancia de la información solicitada, aunque el procedimiento aún no se

${ }^{44}$ Vid. STJUE, de 16 de mayo de 2017, Asunto Berlioz Investment Fund S.A., C-682/15. 
encuentre iniciado» ${ }^{45}$. Sin embargo, a tenor de lo dispuesto en el art. 177 del RGGIT parece que sí habría que entender que esos requerimientos de información sí que pueden constituir la iniciación de oficio del procedimiento inspector ya que, «el procedimiento inspector podrá iniciarse mediante comunicación notificada al obligado tributario para que se persone en el lugar, día y hora que se le señale y tenga a disposición de los órganos de inspección o aporte la documentación y demás elementos que se estimen necesarios en los términos del artículo 87 ».

\section{CESIÓN O UTILIZACIÓN DE DATOS EN LOS PROCEDIMIENTOS SANCIONADORES}

Tal y como hemos visto tras el análisis de la jurisprudencia constitucional, la separación del procedimiento sancionador tributario del resto de procedimientos de aplicación de los tributos no es una exigencia constitucional ${ }^{46}$. El legislador es soberano para configurar la naturaleza de este procedimiento, ya que no existe ningún precepto en la Carta Magna que le imponga una u otra opción. Como el TEDH ha manifestado, el artículo 6 del Convenio Europeo de Derechos Humanos tampoco exige la separación del procedimiento sancionador tributario. En el presente trabajo hemos constatado los perfiles jurídicos tan difusos que ponen en peligro los derechos y garantías consagrados en los arts. $24 \mathrm{CE}$ y 6 del Convenio y por ello resulta trascendental alcanzar posibles vías de solución a estos conflictos.

Resulta obvio que el derecho a no autoincriminarse no puede justificar la negativa del obligado tributario a colaborar con la Administración en los procedimientos de aplicación de los tributos ${ }^{47}$. Como se ha manifestado la con-

${ }^{45}$ Sánchez López, E. M., «Algunas cuestiones controvertidas en relación con los requerimientos de información de terceros. Un análisis jurisprudencial», Quincena Fiscal, núm. 9, (2018): BIB 2018/8646, pág. 11.

${ }^{46}$ Como ha manifestado el Tribunal Constitucional la separación procedimental «es un principio de carácter legal (...), sin que la exigencia de imparcialidad del órgano administrativo sancionador sea, como pretende la entidad recurrente, una garantía derivada, con el carácter de derecho fundamental, del art. 24.2 CE, cuyas exigencias, relativas a la imparcialidad judicial, sólo rigen para el órgano judicial que deba resolver sobre la legalidad de la actuación administrativa» (ATC núm. 186/2008, de 25 de junio, FJ 4º, (RTC 2008, 186 AUTO)).

${ }^{47}$ Como ha declarado parte de la doctrina «El TEDH no afirma de forma expresa el carácter absoluto del derecho a no declarar (...). Al eludir pronunciarse de modo genérico sobre la cuestión, el TEDH deja abierta la puerta a que exista un grado de interés general que justifique la limitación del derecho (...). Llevar las propuestas doctrinales planteadas a sus últimas consecuencias, suprimiendo el deber de colaborar en el procedimiento inspector, supondría el abandono de la potestad sancionadora con grave quebranto de la eficacia del sistema tributario y, en consecuencia, del artículo 31 de la Constitución, o bien 
secuencia de la tesis maximalista que encuentra legítima esta negativa, «es que la obligatoriedad de los documentos pierde su finalidad principal, el aseguramiento de la gestión del tributo frente a la defraudación o la desidia, en la medida en que documentar de manera irregular conlleva eventualmente el mismo resultado para el contribuyente que cuando se cumplen todas las obligaciones tributarias» ${ }^{48}$.

Pero por otro lado, «el reconocimiento de unos hechos en un determinado procedimiento de gestión o inspección no puede extenderse a otros procedimientos sancionadores» ${ }^{49}$. Además, la «cuestión adquiere una mayor relevancia -si cabe- en los supuestos de delito fiscal, cuando la querella se basa en el informe de la inspección, que a su vez se ha elaborado a partir de la documentación suministrada por parte del propio inculpado $»^{50}$.

A continuación, vamos a analizar cuál es el tratamiento dispensado a esta materia por nuestra Ley General Tributaria.

\section{Separación del procedimiento sancionador tributario de «segundo grado»}

Con carácter general, la Ley General Tributaria estableció en el art. 208. $1 \mathrm{el}$ «Derecho a un procedimiento sancionador separado». Dispone la norma que el «procedimiento sancionador en materia tributaria se tramitará de forma separada a los de aplicación de los tributos regulados en el título III de esta ley, salvo renuncia del obligado tributario, en cuyo caso se tramitará conjuntamente».

daría lugar a la generalización de las estimaciones indirectas, que tampoco favorece la seguridad jurídica que proclama el artículo 9 de la propia Constitución» (Mestre García, E., y Cervantes Sánchez-Rodrigo, C.J., Guía de Infracciones y Sanciones Tributarias, op. cit., pág. 216).

${ }_{48}$ Tal y como ha señalado Martínez Muñoz, Y., «consideramos que las actuaciones y procedimientos de aplicación de los tributos regulados en el Título VI de la LGT, en la medida en que constituyen la antesala de un enjuiciamiento penal, adquiriendo en consecuencia cierta finalidad represiva de la conducta del contribuyente, deben suponer un justo balance entre el respeto de los derechos de los obligados tributarios y el ejercicio de una potestad administrativa destinada al cobro de aquellas deudas tributarias de más elevada cuantía» («Los procedimientos tributarios y el delito fiscal en la Ley General Tributaria. Un análisis en el marco de los principios fundamentales del ordenamiento tributario», Quincena Fiscal, núm. 6, (2016): BIB 2016/1022, pág. 2).

${ }^{49}$ Falcón y Tella, R., «El derecho a no declarar y la inviolabilidad del domicilio: la STC 54/2015, de 16 de marzo» (BIB 2015, 2484), Quincena Fiscal, núm. 13, (2015): pág. 14.

${ }^{50}$ Casas Agudo, D., «A vueltas con el derecho a no autoinculparse y su dialéctica con los deberes de colaboración tributaria», Quincena Fiscal, núm. 10, (2017): BIB 2017/11159, pág. 3. 


\subsection{Incorporación de los datos obtenidos en los procedimientos de aplicación de los tributos al procedimiento sancionador}

Sin embargo, esta previsión garantista ha encontrado un obstáculo insalvable en el artículo 210.2 LGT que dispone que, los «datos, pruebas o circunstancias que obren o hayan sido obtenidos en alguno de los procedimientos de aplicación de los tributos regulados en el título III de esta ley y vayan a ser tenidos en cuenta en el procedimiento sancionador deberán incorporarse formalmente al mismo antes de la propuesta de resolución.»

La Ley General Tributaria debería haber sido más clara a la hora de especificar qué se entiende por incorporación formal de todos esos datos y pruebas. Es decir, se tendría que haber fijado nítidamente como se debe llevar a cabo esa incorporación ${ }^{51}$. Con esta anexión se pueden utilizar datos o pruebas que pueden atentar contra el derecho constitucional a no confesarse culpable y a no declarar contra sí mismo ${ }^{52}$. Ya hemos hecho referencia a la doctrina sentada por el TEDH, que propugna una plena incomunicación en materia de prueba dentro de un procedimiento con alcance represivo ${ }^{53}$. En numerosos

${ }^{51}$ Sobre la posible vulneración del derecho a la prueba en el procedimiento sancionador tributario puede verse a De Miguel Arias, S., «La vulneración del derecho a la prueba en el procedimiento sancionador tributario: presupuestos y consecuencias», Jurisprudencia Tributaria, núm. 22, (2008): págs. 19 y ss.

52 Algún Tribunal Superior de Justicia ha considerado como vicio no invalidante del procedimiento sancionador el hecho de que no se hubiera incorporado una diligencia, si al expediente sancionador se habían incorporado las actas que reprodujeron esa diligencia. Puede verse al respecto la Sentencia del Tribunal Superior de Justicia de Murcia de 26 de febrero de 2003 (JT 2003, 782). También el Tribunal Económico Administrativo Central ha considerado que no se ha cumplido el deber de incorporar formalmente al expediente los datos y documentos obtenidos durante la inspección, dado que el imputado había firmado el acta de conformidad y ya era conocedor de los datos o derechos imputados (Resolución de 4 de junio de 2003).

${ }^{53}$ Como ha sintetizado Casanova Caballero, C., durante «la tramitación del Proyecto, el Cuerpo de Letrados de las Cortes ha citado la doctrina del TEDH para propugnar, sin éxito, la modificación del Proyecto. Esta pretensión tiene un antecedente en la propuesta de un amplio sector de la doctrina española de que la doctrina sentada por el TEDH se incorpora a la LDGC (Banacloche, Palao Taboada, Zornoza, Falcón y Tella, etc.) bajo el principio que nadie debe verse forzado a declarar en propio perjuicio. También se afirma que nuestro propio TC, en su Sentencia de 26 de abril de 1990 parece haber llegado a otra conclusión, pero, en nuestra opinión, se limitaba a afirmar que el derecho a no declararse culpable no puede alegarse en el procedimiento de gestión tributaria, sin que en ningún momento el TC afirmase que fuera inaplicable en un procedimiento administrativo sancionador, lo cual nos lleva evidentemente al tema de la intercomunicación de datos ya apuntado. En todo caso, no se puede negar que el Tribunal Constitucional es consciente del problema y lo afronta así en la sentencia 110/1984, de 26 de noviembre y concluye que al obligado tributario se le impone el deber de aportar los datos que puedan ayudar a la 
pronunciamientos de este Tribunal a los que hemos hecho referencia se ha ido consolidando toda una doctrina en torno al derecho a no autoinculparse, que pone en tela de juicio nuestro sistema actual para la obtención de pruebas para los procedimientos tributarios y su posible utilización ulterior en el procedimiento sancionador o incluso en un proceso penal.

A nuestro juicio, hubiera sido deseable una mayor claridad por parte del legislador a la hora de especificar el contenido de esta incorporación. Esta literalidad ambigua deja en manos del órgano instructor incorporar lo que le interesa y lo que no, o simplemente no hacerlo por remisión a un acta diligencia firmada en conformidad ${ }^{54}$.

Pero no estamos ante una cuestión de mero trámite ya que esta previsión puede tener unos efectos trascendentales. Esta incorporación puede suponer la utilización en el procedimiento sancionador de declaraciones incriminatorias que se han obtenido durante las actuaciones de comprobación. Nos encontramos ante uno de los grandes conflictos en nuestro derecho financiero y tributario: la posible vulneración del derecho a no declarar contra sí mismo. Para garantizar el derecho a la prueba del presunto infractor el artículo 23.4 del RGRST establece el derecho a la audiencia disponiendo que los «interesados podrán formular alegaciones y aportar los documentos, justificantes y pruebas que estimen convenientes en cualquier momento anterior a la propuesta de resolución». El interesado podrá formular alegaciones en cualquier momento de la instrucción como consecuencia del principio de contradicción que se deriva del art. 24.2 de la Constitución y que también es aplicable en el procedimiento sancionador tributario ${ }^{55}$.

\subsection{Datos que constituyen una declaración autoincriminatoria}

En términos generales la doctrina ha razonado la separación del procedimiento sancionador en el derecho a no autoincriminarse, a no declarar contra sí mismo, tantas veces puesto en peligro en las normas analizadas. Nos

investigación, pero no se le exige que declare contra sí mismo» (en AA VV, coord. Mantero Sáenz, A., y Giménez-Reyna Rodríguez, E., Ley General Tributaria. Antecedentes y comentarios, (Asociación Española de Asesores Fiscales, Madrid, 2005), pág. 887).

${ }_{54}$ Sobre este particular se ha advertido que «debería eliminarse del informe correspondiente en el que se hacen constar los resultados de las actuaciones practicadas todos aquellos datos derivados de la confesión o aportación de pruebas por parte del obligado tributario bajo la amenaza de una sanción», (Ribes Ribes, A., «El derecho a no declarar contra sí mismo y el principio non bis in idem en materia tributaria, a la luz de la doctrina del Tribunal Constitucional y del Tribunal Europeo de Derechos Humanos», (VI Congreso Tributario, AEDAF, 2011), pág. 410).

55 En este sentido, Fuster Asencio, C., El procedimiento Sancionador Tributario, op. cit., pág. 216. 
hallamos ante derechos fundamentales consagrados por el artículo 24.2 de la Constitución y que en la mayoría de los casos ceden ante el crédito tributario $^{56}$. Sin embargo, del análisis del artículo 210.2 de la Ley General Tributaria hemos comprobado que los datos, pruebas o circunstancias que obren o hayan sido obtenidos en el procedimiento de aplicación de los tributos y vayan a ser tenidos en cuenta en el procedimiento sancionador, deberán incorporarse formalmente al mismo antes de la propuesta de resolución. Como ya hemos manifestado la norma no nos parece acertada, pero parece encontrase enmarcada en la línea seguida por el Tribunal Constitucional. Las propuestas que se han apuntado para resolver este problema son diferentes y de muy distinto alcance.

Básicamente, algunos autores piensan que no existe tensión alguna entre el deber de colaborar y el derecho a no autoincriminarse. En el procedimiento de comprobación es exigible el deber de colaborar y posteriormente es posible utilizar las pruebas obtenidas en el procedimiento sancionador ${ }^{57}$.

Sin embargo, hay quienes sostienen que el derecho a la no autoincriminación debe ser interpretado como derecho a no ser condenado o sancionado con fundamento en la información autoincriminatoria aportada bajo coacción. El deber de colaboración y las sanciones por su incumplimiento permanecerían plenamente vigentes durante los procedimientos de comprobación e investigación, pero en el procedimiento sancionador no podría utilizarse aquella información aportada bajo amenaza de sanción y que resulte autoincrinatoria ${ }^{58}$.

En tercer lugar y, en nuestra opinión, habría que distinguir qué tipo de datos y su posible aportación constituyen una violación desde el punto de vista del derecho a no autoincriminarse. Todos aquellos datos que no constituyen una declaración a los efectos de este derecho fundamental sé podrían incorporar a un posible procedimiento sancionador, básicamente porque no dependen de la propia voluntad del presunto infractor. De hecho, podría realizarse una interpretación correctora del art. 210 de la LGT en el sentido de que solamente pueden incorporarse al procedimiento sancionador aquellos 368.

${ }^{56}$ Vid. Pérez Royo, F., Derecho Financiero y Tributario. Parte General, op. cit., pág.

57 Vid. Del Paso Bengoa, J.M. y Jiménez Jiménez, C., Derechos y Garantías del Contribuyente. Comentarios a la Ley 1/1998, op. cit., págs. 396, 409 y 415.

58 Vid. Falcón Y Tella, R., «El carácter reservado de la información tributaria: la Sentencia Saunders y sus consecuencias sobre el ordenamiento interno», Quincena Fiscal, núm. 12, (1997): pág. 6; Escribano López, F., «El procedimiento sancionador en la Ley de derechos y garantías de los contribuyentes y su desarrollo reglamentario», op. cit., pág. 18; Aguallo Avilés y García Berro, F., «El deber de colaborar con la Administración tributaria y el derecho a no autoincriminarse: un conflicto aparente», en la obra colectiva, El asesor fiscal ante el nuevo siglo, (AEDAF, Madrid, 2004), págs. 75 y ss. 
datos que son susceptibles de utilización con fines represivos ${ }^{59}$. Y aquí es donde se echa en falta una respuesta del Tribunal Constitucional que, amparándose en formalismos, ha eludido interpretar y llenar de contenido este derecho fundamental en el procedimiento sancionador tributario. La necesidad «de que exista una vinculación real y concreta entre el deber de colaboración del obligado tributario y la pretensión de sancionarle para habilitar esta anticipación del derecho a no autoinculparse constituye un criterio potencialmente generador de una extraordinaria inseguridad jurídica y susceptible de generar elevadas dosis de arbitrariedad y litigiosidad $»^{60}$.

Como ya ha advertido la doctrina a raíz de los pronunciamientos del TEDH, el derecho a no autoincriminarse no ampara la negativa a aportar datos que tengan una existencia independiente de la voluntad del sujeto ${ }^{61}$. Tal y como se ha analizado, el TEDH ha hecho referencia a la aportación de información y documentos «obtenidos en virtud de un mandato» (asunto Saunders). Se trataría de documentos cuya producción, conservación, aportación u obtención vienen determinados por una ley, como el deber de llevar contabilidad o registros fiscales ${ }^{62}$. En esta línea resultan muy clarificadoras las manifestaciones del TEDH en el asunto Jalloh contra Alemania, para entender el concepto de declaración autoincriminatoria. Respecto a la utilización de pruebas obtenidas en violación del derecho a guardar silencio y del derecho a no autoinculparse «no se extiende al uso, en un procedimiento penal, de datos que se pueden obtener del acusado recurriendo a métodos coercitivos sino que existen independientemente de la voluntad del sospechoso, por ejemplo, los documentos obtenidos en virtud de una orden, las extracciones de sangre, el aliento, las muestras de orina, cabellos y tejidos corporales con vistas a un análisis de ADN o incluso de voz».

Sobre el contenido del derecho a no autoincriminarse y el deber de colaboración destacan las aportaciones realizadas por LOZANO SERRANO ${ }^{63}$ en relación a los datos que quedarían amparados por este derecho y que no podrían requerírsele para después utilizase en un procedimiento sancionador, tales como extractos de movimientos bancarios, justificantes o antecedentes de operaciones que no deban incorporarse a la contabilidad, relación de todas

59 Vid. García Berro, F., «Derecho a no autoincriminarse de los contribuyentes y procedimiento sancionador separado», op. cit., pág. 15.

${ }^{60}$ Casas Agudo, D., «A vueltas con el Derecho a no autoinculparse y su dialéctica con los deberes de colaboración tributaria», op.cit., pág. 17.

${ }^{61}$ Vid. García Novoa, C., «Una aproximación del Tribunal Constitucional al derecho a no autoincriminarse ante la Inspección Tributaria en relación con los delitos contra la Hacienda Pública», Jurisprudencia Tributaria Aranzadi, núm. 53, (2005): pág. 1.

${ }^{62}$ Obligación legal derivada de los arts. 25 y ss del Código de Comercio.

${ }^{63}$ Lozano Serrano, C., «El Deber de colaboración tributaria sin autoincriminación», Quincena Fiscal, núm. 8, (2015): BIB 2015/1254. 
las transmisiones y adquisiciones de la persona física, la documentación y los antecedentes de negocios jurídicos, etc.

\subsection{Derecho al juez imparcial}

Pero los derechos fundamentales del obligado tributario se encuentran aún más controvertidos si atendemos a lo dispuesto en el art. 211.5 LGT, según el cual «Son órganos competentes para la imposición de sanciones: d) El órgano competente para liquidar o el órgano superior inmediato de la unidad administrativa que ha propuesto el inicio del procedimiento sancionador». La norma establece que la instrucción y resolución será por el mismo órgano por lo tanto nos surge la duda de si en este procedimiento punitivo, además de existir un trasvase de información obtenida en los procedimientos de aplicación ¿Se respeta el derecho a un juez imparcial? La doctrina constitucional ha ido perfilando a lo largo de los años el derecho al juez imparcial enmarcado dentro del derecho más amplio a un proceso con todas las garantías $^{64}$. Con respecto a este derecho y refiriéndose al proceso penal, ha declarado el Tribunal Constitucional en su Sentencia 145/1988, de 12 de julio (RTC 1988, 145):

«...el derecho a un Juez imparcial...constituye sin duda una garantía fundamental de la Administración de Justicia en un Estado de Derecho, como es el nuestro de acuerdo con el artículo 1.1 de la Constitución...la actividad instructora, en cuanto pone al que la lleva a cabo en contacto directo con el acusado y con los hechos y datos que deben servir para averiguar el delito y sus posibles responsabilidades puede provocaren el ánimo del instructor, incluso a pesar de sus mejores deseos, prejuicios o impresiones a favor o en contra del acusado que influyan a la hora de sentenciar. Incluso aunque ello no suceda es difícil evitar la impresión de que el Juez no acomode la función de juzgar sin la plena imparcialidad que le es exigible». Y en la STC 106/1989 de 8 de junio (RTC 1989, 106) advirtió que la «necesidad de atribuir la fase de instrucción y la del juicio oral a dos distintos órganos jurisdiccionales conforma hoy, frente al proceso penal inquisitivo del antiguo régimen, la primera nota que ha de concurrir en un proceso penal acusatorio».

Como puede verse según el Tribunal Constitucional la imparcialidad no es predicable de quien asume simultáneamente las funciones de instrucción y decisión. De esta garantía se deriva la necesidad de atribuir las labores de

${ }^{64}$ Pueden consultarse diferentes Sentencias de nuestro más alto tribunal en las que se recoge el contenido del derecho al Juez imparcial, entre las mismas destacan: SSTC 64/1997, de 7 de abril (RTC 1997, 64); 98/1997, de 20 de mayo (RTC 1997, 98); 6/1998, de 13 de enero (RTC 1998, 6). 
instrucción y de enjuiciamiento a órganos diferentes, todo ello en aras de garantizar la máxima objetividad. Ahora bien, como hemos analizado todos estos pronunciamientos están referidos al orden jurisdiccional donde no cabe duda que el derecho al juez imparcial despliega toda su eficacia. Sin embargo, con respecto a la separación de las funciones de instrucción y decisión y su posible aplicación al ámbito administrativo, no existe un consenso generalizado que avale la traslación del derecho al juez imparcial a la esfera sancionadora administrativa ${ }^{65}$. El Tribunal Constitucional sí se ha pronunciado en relación a la aplicación del derecho al juez imparcial en el ámbito administrativo sancionador y ha matizado el contenido de esta garantía afirmando que, aunque la misma es de ineludible aplicación al orden jurisdiccional no presupone obligatoriamente su aplicación en el orden administrativo sancionador ${ }^{66}$. En la misma línea ha declarado el Tribunal Constitucional en la Sentencia 76/1990, de 26 de abril con respecto a la inspección tributaria que «...tanto si se separan las funciones inspectoras de las liquidadoras como si se atribuyen a un mismo órgano el contribuyente estará siempre ante una misma organización administrativa estructurada conforme a un principio de jerarquía, y esta circunstancia a diferencia de lo que ocurre en los procedimientos judiciales, impide una absoluta independencia «ad extra» de los órganos administrativos tributarios, cualquiera que sea el criterio de distribución de funciones entre los mismos ${ }^{67}$. Como puede comprobarse, en los anteriores pronunciamientos el Tribunal Constitucional hace referencia a dos procedimientos administrativos:

${ }^{65}$ Por ello se ha llegado a advertir que sólo «una mimética y precipitada traslación al ámbito administrativo de los derechos consagrados en el art. $24 \mathrm{CE}$ ha podido determinar que el «derecho a un juez imparcial», elaborado por la doctrina del Tribunal Constitucional bajo la cobertura del «derecho a un proceso con todas las garantías» (art. 24.2 CE), haya sido implantado en el art. 134.2 LRJ-PAC, en el que se ordena que las fases de instrucción y decisión de los procedimientos sancionadores sean encomendadas a «órganos distintos»»" (Garberí Llobregat, J., y Buitrón Ramírez, G., en la obra colectiva, Procedimientos Sancionador, Infracciones y Sanciones Tributarias (Comentarios, Jurisprudencia, Formularios, Ejemplos Prácticos y Legislación), t. I, (Tirant lo Blanch, Valencia, 2005), pág. 140.)

${ }_{66} \mathrm{El}$ derecho «al Juez ordinario es una garantía característica del proceso judicial que no se extiende al procedimiento administrativo porque, sin perjuicio de la interdicción de toda arbitrariedad y de la posterior revisión judicial de la sanción, la estricta imparcialidad e independencia de los órganos del poder judicial no es, por esencia, predicable en la misma medida de un órgano administrativo» (STC 22/1990, de 15 de febrero (RTC 1990, 22)).

${ }^{67}$ Continúa el Tribunal manifestando que «Por la naturaleza misma de los procedimientos administrativos, en ningún caso puede exigirse una separación entre instrucción y resolución equivalente a la que respecto de los Jueces ha de darse en los procesos Jurisdiccionales. El derecho al juez ordinario predeterminado por la Ley y a un proceso con todas las garantías - entre ellas, la independencia e imparcialidad del juzgador- es una garantía característica del proceso judicial que no se extiende al procedimiento administrativo, ya que la estricta imparcialidad e independencia de los órganos del poder judicial, 
los procedimientos de comprobación y liquidación. Por lo tanto, esta doctrina al referirse específicamente a esos procedimientos manifiesta una enrome generalidad que no justifica que deba trasladarse estrictamente al ámbito sancionador. En cualquier caso, desde nuestro punto de vista, la acumulación de funciones liquidadoras, inspectoras y sancionadoras en la inspección de los tributos compromete la imparcialidad de este órgano cuando actúa en el ejercicio del poder punitivo del Estado, quebrantado el derecho a un proceso con todas las garantías (art. 24.2 de la Constitución) y en particular el derecho a un juez imparcial. Para respetar este derecho fundamental el legislador no dispone de un «amplio margen» para decidir acerca de la separación o la acumulación de las funciones de inspección y de resolución en unos mismos órganos. La cuestión fundamental que habría que desentrañar es si la Administración cuando actúa en el ejercicio del «ius puniendi» estatal lo hace con desinterés o interés objetivo. Si actúa con desinterés objetivo se le exige aquí un juicio objetivo de los intereses en juego, en cambio, si actúa con interés objetivo, la administración actúa en asunto propio y, por tanto, no hay desinterés. Aunque la imparcialidad y la independencia de los órganos del poder judicial, no se puede predicar en la misma medida de un órgano administrativo que se encuentra bajo la órbita del principio de jerarquía, sin embargo, desde nuestro punto de vista resulta ineludible garantizar y exigir un mínimo de garantías en aras de los derechos de los administrados. El principio de independencia y de imparcialidad no puede ceder totalmente ante el principio de jerarquía y de eficacia en la actuación administrativa. Aunque la Administración actúe bajo los parámetros de autotutela. Precisamente por ello, cuando se es juez y parte al mismo tiempo se debe velar más celosamente por las garantías de los administrados ${ }^{68}$.

\section{Separación del procedimiento sancionador de «primer grado»}

\subsection{Separación orgánica}

En nuestro trabajo hemos hecho referencia a dos niveles diferentes de separación del procedimiento sancionador. En primer lugar, hemos

no es, por esencia, predicable con igual significado y en la misma medida de los órganos administrativos» (STC 76/1990, de 26 de abril (RTC 1990, 76)).

${ }^{68}$ Como ha señalado Suay Rincón, J., se hace absolutamente necesario afianzar la vigencia de la imparcialidad dentro del procedimiento administrativo sancionador, «la sanción administrativa es siempre el resultado de un juicio sobre la conducta llevada a cabo por una determinada persona, y todo juicio reclama por esencia una cierta dosis de imparcialidad, un cierto alejamiento de las posiciones de las partes implicadas en el conflicto» («La discutible vigencia de los principios de imparcialidad y contradicción en el procedimiento administrativo sancionador», Revista de Administración Pública, núm. 123, (1990): págs. 170 y 171). 
distinguido la separación del procedimiento sancionador de «segundo grado», que quedaría satisfecha con la tramitación del procedimiento sancionador en un expediente separado del resto de procedimientos de aplicación de los tributos. Esta separación procedimental fue la que exigió en su momento la Ley 1/1998 y que continúa vigente como principio general en la nueva ley general tributaria. Sin embargo, a nuestro juicio, debería existir una separación del procedimiento mucho más estricta que requiere no sólo la separación del expediente sancionador, sino la atribución de las fases de instrucción y resolución a órganos diferentes, dando lugar a la separación del procedimiento sancionador «de primer grado». Quizás en futuro podría habilitarse un departamento específico dentro de la Administración tributaria que tuviera por objeto el ejercicio de la potestad sancionadora, pues solamente con la independencia del órgano sancionador quedará salvaguardada la objetividad exigible por nuestra Constitución y los derechos de defensa del administrado.

\subsection{Régimen probatorio diferenciado}

En nuestra opinión, la separación del procedimiento sancionador debería de haber incorporado un régimen probatorio diferenciado, donde el presunto infractor pueda ejercitar sus derechos de defensa. La culpabilidad no debería ser probada por la sola incorporación de los datos obtenidos en el procedimiento de comprobación. Este último procedimiento tiene una finalidad distinta cual es la determinación de la deuda y, precisamente por ello el contribuyente tiene la obligación de colaborar bajo amenaza de sanción. Las pruebas autoincriminatorias que constituyen una declaración desde el punto de vista de los derechos de defensa, solo deberían tener efecto sobre la liquidación de la deuda tributaria. Hubiera sido deseable establecer en el procedimiento sancionador que la prueba de la sanción no puede derivar exclusivamente de los datos aportados en la comprobación y bajo amenaza de sanción. El procedimiento sancionador debe tener un contenido instructor propio, donde se valoren y acrediten todas las pruebas y material de cargo. Lo que no es admisible es la separación del procedimiento sancionador tributario como principio general y permitir una comunicación con el resto de procedimientos de aplicación de los tributos.

\section{REFLEXIÓN FINAL}

Tras realizar un acercamiento al deber de colaboración y los derechos de defensa del obligado tributario, podemos concluir que los procedimientos sancionadores se encuentran estrechamente relacionados con los procedimientos de aplicación de los tributos del Título VI de la LGT. A nuestro 
juicio, la multitud de requerimientos de información que recibe el contribuyente deben notificarse e incluir la correspondiente motivación para que el obligado tributario pueda ejercitar sus derechos de defensa, en el supuesto de que sean datos o información que puedan constituir una declaración incriminatoria.

No se pueden seguir sacrificando las garantías de los contribuyentes, en aras de la comodidad y eficacia de la Administración tributaria. No se puede permitir por la «Ley» General Tributaria que la Administración utilice todas sus prerrogativas y poderes para obtener datos e información, bajo amenaza de sanción y que luego los utilice para incriminar al administrado. En la actualidad la Administración dispone de medios para poder llevar a cabo una actividad de cargo que no se base en exclusiva en lo aportado por el contribuyente en los procedimientos de aplicación de los tributos.

El procedimiento sancionador debe tener un contenido instructor propio donde se valoren y acrediten todas las pruebas y material de cargo por el propio instructor del mismo. Deben regir pautas diferentes de las seguidas por el procedimiento de determinación de la deuda, y se debe inspirar en el principio de presunción de inocencia. En cualquier caso, lo que no es admisible es la afirmación de la separación del procedimiento sancionador tributario como principio general y permitir una total comunicación con el resto de procedimientos. Esto genera una confusión en el contribuyente que se ha de denunciar. 


\title{
LOS DERECHOS DE DEFENSA Y EL DEBER DE COLABORACIÓN CON LA ADMINISTRACIÓN TRIBUTARIA
}

\author{
Defense rights and the duty of collaboration \\ with the tax administration
}

\author{
Montserrat Hermosín Álvarez \\ Universidad Pablo de Olavide (España) \\ mheralv@upo.es
}

http://dx.doi.org/10.18543/ed-66(2)-2018pp219-248

\section{Copyright}

Estudios de Deusto es una revista de acceso abierto, lo que significa que es de libre acceso en su integridad. Se permite su lectura, la búsqueda, descarga, distribución y reutilización legal en cualquier tipo de soporte sólo para fines no comerciales, sin la previa autorización del editor o el autor, siempre que la obra original sea debidamente citada y cualquier cambio en el original esté claramente indicado 